\title{
Is the Stock Market Immune to COVID-19? Evidence from Malaysian Stock Market
}

Kelvin Lee Yong Ming, Ling Pick Soon, Mohamad Jais

To Link this Article: http://dx.doi.org/10.6007/IJARAFMS/v12-i1/12308 DOI:10.6007/IJARAFMS /v12-i1/12308

Received: 11 Deceember 2021, Revised: 13 January 2022, Accepted: 27 January 2022

Published Online: 20 February 2022

In-Text Citation: (Ming et al., 2022)

To Cite this Article: Ming, K. L. Y., Soon, L. P., \& Jais, M. (2022). Is the Stock Market Immune to COVID-19? Evidence from Malaysian Stock Market. International Journal of Academic Research in Accounting Finance and Management Sciences, 12(1), 212-227.

Copyright: @ 2022 The Author(s)

Published by Human Resource Management Academic Research Society (www.hrmars.com)

This article is published under the Creative Commons Attribution (CC BY 4.0) license. Anyone may reproduce, distribute, translate and create derivative works of this article (for both commercial and non-commercial purposes), subject to full attribution to the original publication and authors. The full terms of this license may be seen at: http://creativecommons.org/licences/by/4.0/legalcode

Vol. 12, No. 1, 2022, Pg. 212 - 227

Full Terms \& Conditions of access and use can be found at http://hrmars.com/index.php/pages/detail/publication-ethics 


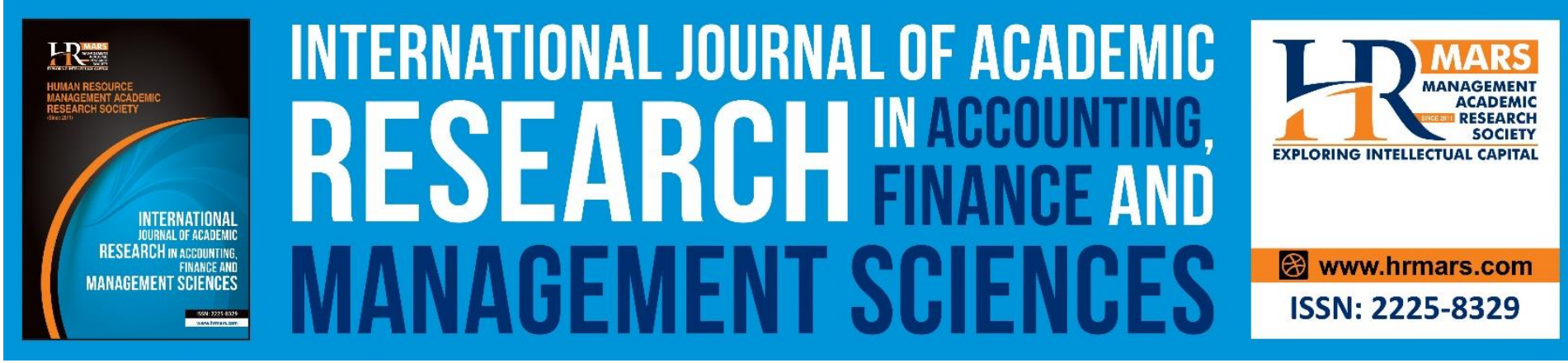

\title{
Is the Stock Market Immune to COVID-19? Evidence from Malaysian Stock Market
}

\author{
Kelvin Lee Yong Ming ${ }^{\mathrm{a}}$, Ling Pick Soon ${ }^{\mathrm{b}}$, Mohamad Jais ${ }^{\mathrm{c}}$ \\ Taylor's Business School, Taylor's Universitya, School of Business and Management, \\ University of Technology Sarawak ${ }^{\text {b }}$, Faculty of Economics and Business, Universiti Malaysia \\ Sarawak
}

\begin{abstract}
This study aims to examine the immunity of the Malaysian sectoral indexes to the COVID-19 related news in 2020 and 2021 . The findings indicated that the market volatility of the Malaysian stock market has reduced from 2020 to 2021. The results also showed that market volatility and Brent oil price movements had a significant impact on the majority of the sectors. The daily COVID-19 confirmed cases also had a greater impact than the daily COVID19 death cases towards the movements of Malaysian sectorial indexes. Investors are recommended to monitor the information related to the COVID-19 pandemic. Any dramatic changes in COVID-19 confirmed cases and death cases might cause another round of volatility in the Malaysian stock market. Risk-averse investors are recommended to pay attention to the consumer product and construction sectors. Lastly, REIT, technology, and healthcare sectors shall be another sector to be targeted after the reopening of economic activities.
\end{abstract}

Keywords: COVID-19 Pandemic, Sectoral Indexes, Stock Market

\section{Introduction}

Since the reports of novel coronavirus (COVID-19) in China first surfaced in late 2019, the global epidemic has claimed many lives and continues to wreak havoc on the global economy. While the pandemic has affected almost every country, the reactions towards the pandemic have significantly varied across the countries (Fernandez-Perez et al., 2021). Governments worldwide also have implemented lockdowns, travel restrictions, and quarantined infected patients. The fundamental goal of these activities was to maintain social distance between people to prevent the disease's spread. However, these efforts have also affected the jobs and earnings of tens of millions of people. Consequently, the pandemic has slowdown economic activities for the past two years. Fiscal and monetary adjustments are needed to deal with the issues. The governments also implemented various economic stimulus measures to minimize the negative impacts on the economic system. The long-term financial implications are expected to take years to manifest (Stubbs et al., 2020).

The unprecedented COVID-19 pandemic has shifted the global landscape in unanticipated ways. It also heavily disrupted global stock market movements. Asian financial markets witnessed an abrupt slump when the outbreak occurred (Liu et al., 2020). After the COVID-19 pandemic extended to Italy, the US and European stock markets collapsed 
MANAGEMENT SCIENCES

Vol. 12, No. 1, 2022, E-ISSN: 2225-8329 ๔ 2022 HRMARS

dramatically (Gormsen \& Koijen, 2020). Specifically, the market reactions to early COVID-19 outbreaks were more immediate and larger in nations that experienced SARS in 2003 (Ru et al., 2021). The Malaysian governments also came out with different strategies to curb the spreading of COVID-19, such as the Movement Control Order (MCO). MCO also limits the movements of Malaysian during the journey fighting against the COVID-19 virus (Rahim et al., 2021). These also harmed the economic activities and led to a greater fluctuation in the Malaysian stock market. The Malaysian government also announced various economic stimulus packages to boost investor confidence, resulting in a positive movement in the stock market after that (Rahman et al., 2021).

\section{COVID-19 Situation and Malaysian Stock Market}

Figure 1 shows the daily COVID-19 cases in Malaysia and Kuala Lumpur Composite Index (KLCl) movements throughout March 2020 to December 2020. On 18 March 2020, the Malaysian government implemented the movement control order (MCO) to curb the spreading of COVID-19. The next day after the implementation of $\mathrm{MCO}, \mathrm{KLCl}$ also slumped to only 1219.72 points. The implementation of MCO also caused the COVID-19 cases to experience a significant reduction and reached the number of 0 cases on 2 July 2020 . With the reduction of COVID-19 cases, the $\mathrm{KLCl}$ also started to rebound and hit the level of 1,611.42 on 29 July 2020. However, another wave of COVID-19 pandemic hit Malaysia around September 2020. During this period, $\mathrm{KLCl}$ also experienced some adjustment, then reversed to below 1500. Surprisingly, the $\mathrm{KLCl}$ also nearly broke the level of 1700 on 11 December 2020, despite the COVID-cases generally rising from October to December 2020.

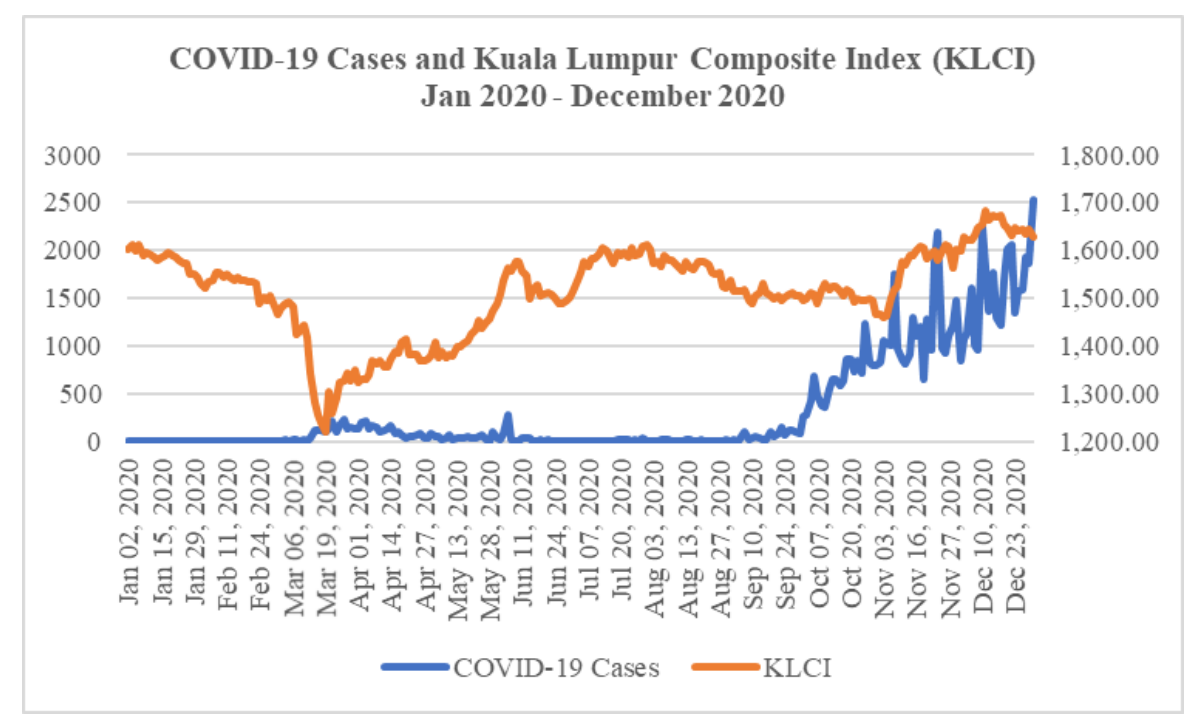

Figure 1: COVID-19 Cases and Kuala Lumpur Composite Index (KLCI) (Jan 2020 - Dec 2020) 


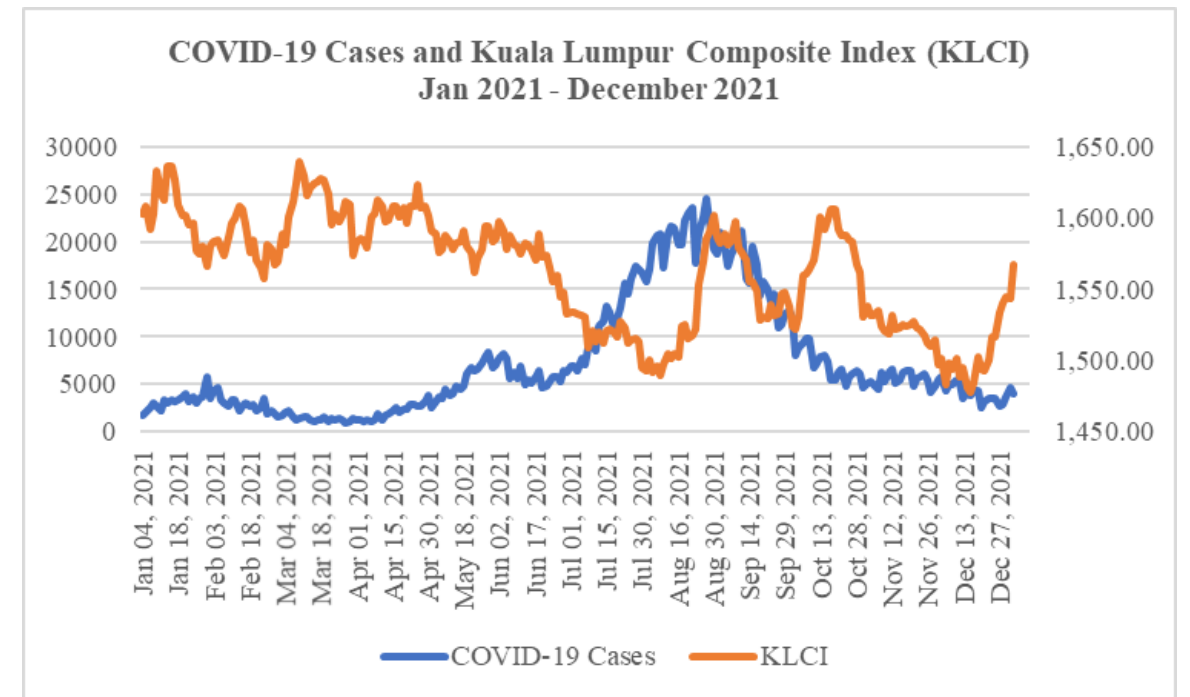

Figure 2: COVID-19 Cases and Kuala Lumpur Composite Index (KLCI) Movements (Jan 2021 Dec 2021)

Figure 2 shows the daily COVID-19 cases in Malaysia and Kuala Lumpur Composite Index (KLCl) movements from January 2021 to October 2021. Generally, the Malaysian stock market had a sideways pattern in the first quarter. Meanwhile, the COVID-19 cases have shown a declining trend. After April 2021, the COVID-19 cases followed the rising trend and hit the highest number of 24,599 cases on 26 August 2021. High number of COVID-19 cases are also recorded in Malaysia between August 2021 and September 2021. However, the KLCl rebounded from only 1489.80 points on 6 August 2021 to 1597.63 points on 8 September 2021. The COVID-19 cases also experienced a downward trend after hitting the peak on August 2021. Interestingly, the $\mathrm{KLCl}$ also experienced a similar trend and touch the level of $1,480.92$ on 14 December 2021. Although the COVID-19 cases have declined recently, the $\mathrm{KLCl}$ does not show a significant upward trend.

\section{Motivation of the Study}

Previous empirical studies have mainly used the major indexes as the sample of study, which might offer less information about a particular market. Thus, all the sectoral indexes from the Malaysian stock market are included as the sample in this study. Then, this study examines the impacts of COVID-19 information on the performance of different sectors. Second, the sample period is divided into two sub-periods, which enables the impacts of COVID-19 to be determined in different periods.

Indeed, previous studies have shown that COVID-19 cases significantly negatively impacted the Malaysian stock market. However, the Malaysian government recently decided to restart the economic activities for nearly all the sectors, and a strong rebound in specific economic sectors has been witnessed. Is the stock market immune to the COVID-19 related news, such as COVID-19 cases and death cases? If the market is immune to the COVID-19 related news, what is the other news that possibly affects the Malaysian stock market movements?

Based on these considerations, this study revisits the relationship between COVID-19 cases and the performance of the Malaysian stock market using the recent data. This paper contributes to the related literature in four main aspects. First, it examines the magnitude of the COVID-19 proxies in affecting the stock market movements over different periods by using 
quantile regression analysis. Second, to capture the potential impacts of COVID-19 on the Malaysian stock market, this study considers both the COVID-19 daily new cases and death cases as the proxies of the COVID-19 situation. Third, this study uses daily data of 13 sectoral indexes over the period January 2020 to December 2021. Fourth, this study compares the impacts of COVID-19 toward sectoral indexes in 2020 and 2021.

Despite a substantial amount of research being conducted, the understanding of the impact of COVID-19 on the stock market remains limited. The frequency of the index jumps during the COVID-19 pandemic is relatively higher than any other period before the pandemic (Baker et al., 2020). Generally, the high geared listed companies were having a tough time during the COVID-19 pandemic. Whereas those companies with better net cash flow showed greater resilience to the impact of the pandemic (Wang et al., 2021).

The following is the overall structure of this study. Section 2 reviews related previous literature. Section 3 discusses the model that was used in this paper, as well as the data. Section 4 covers the result and discussions, and the conclusions is included in Section 5.

\section{Literature Review}

The disease-related news was one of the most significant factors that determined the stock market's movements (Liu et al., 2020; Sun et al., 2021). For instance, Donadelli et al. (2017) show that the fear of deadly contagious diseases such as H1N1 and SARS affected investors' confidence, resulting in a decline in the performance of the stock markets. In the context of COVID-19, previous literatures have shown that the number COVID-19 cases and death cases negatively related with the stock market's performance of different countries, such as the United States (Baek et al., 2020), Hong Kong (Al-Awadhi et al., 2020), China (AlAwadhi et al., 2020) and other Asian countries (Liu et al., 2020). Specifically, both COVID-19 confirmed cases and death cases affected the stock returns and volatility in the emerging market before April 2020. Whereas COVID-19 confirmed cases affected stock returns, volatility, and trading volume in the developed market after April 2020 (Harjoto et al., 2021).

During COVID-19 pandemic, many governments implement the lockdown as the preventive measures to stop the spreading of COVID-19 virus. The lockdown also caused the negative impact to the performance of many sectors, except for the technology, electronic, and healthcare sectors (Alam et al., 2020; Huo \& Qiu, 2020). Most of the firms can only operate at a lower capacity during the lockdown, then they choose to reduce labour expenses by laying off staff. As a result, spending and economic output are sharply reduced (Mazur et al., 2020). In addition, the COVID-19 pandemic caused the investors pessimistic about the stock market's performance, so they are less inclined to make any financial investments in the stock market (Naseem et al., 2021). Public fear and the implementation of lockdown or movement restriction also causing the stock market to be illiquid and instable (Baig et al., 2021).

Furthermore, the COVID-19 pandemic also brought the unprecedent damages to the global airline companies. Following the announcement of COVID-19 pandemic, the airline stock had significantly underperformed the market returns (Maneenop \& Kotcharin, 2020). But COVID-19 related news boosted investor confidence in the pharmaceutical or healthcare industry, resulting in an improvement in the performance of pharmaceutical or healthcare stocks. This expectation is due to investors' anticipation of the increasing demand for pharmaceutical products. The rising trend in pharmaceutical stock price is witnessed during COVID-19 pandemic (Song et al., 2021). However, COVID-19 related news and economic 
related announcements do not cause irrational investment in the pharmaceutical or healthcare stocks (Sun et al., 2021).

He et al (2020) used the event study approach to investigate the impact of COVID-19 pandemic on different sectors in China stock market. The research also revealed that manufacturing, technology and education sectors shown immunity to the COVID-19 pandemic. However, the quarantine measure has limited the movements of individuals or workers, causing the mining and transportation stocks to plunge. On the other hand, the COVID-19 pandemic also adversely affected the tourism sector in China. Venus (2020) recommended the investors to stay away from tourism related stocks whenever there is any sign that a virus outbreak may occur. However, event studies approach can only examine the impact of COVID-19 around the certain date only (Al-Awadhi et al., 2020).

Using event study approach, Liu et al (2020) investigated the impact of COVID-19 pandemic on 21 leading stock indexes around the world. They revealed that the stock markets of Asian countries react more quickly to the COVID-19 pandemic, with some of them recovering slightly in the later stages of the pandemic. Meanwhile, the confirmed cases of COVID-19 had significant negative consequences on the performance of major stock indexes, with those in Asia seeing the most significant reduction in abnormal returns. The dread sentiment of investors has been demonstrated to be a complete mediator for the influence of the COVID-19 pandemic towards stock markets.

Ashraf (2020) examined the impact of the COVID-19 pandemic on the stock market returns of 64 countries. By analysing the daily relevant data, he discovered that stock markets had reacted unfavourably to the increase in COVID-19 confirmed cases. The stock markets were also more reactive to the increase in confirmed cases than the death cases. However, he highlighted that the stock market responds differently over time and by stage of the outbreak.

On the other hand, the Malaysian government has implemented the Movement Order Control (MCO) to curb the spreading of COVID-19 virus (Shah et al., 2020). The MCO has a mild impact on the households' financial condition in the short run (Baharudin et al., 2021). In addition, the MCO harm the bottom line of the firms, then causing the stock prices to plunge at the earlier stage of COVID-19 outbreak (Chia et al., 2020). The previous findings also shown that the daily COVID-19 cases in the past posed a negative effect on the Malaysian stock market activities (Gamal et al., 2021) and other economic performance indicators (Mustaffa et al., 2021). In contrast, the death cases do not pose any significant impact on the Malaysian stock market movements (Chia et al., 2020).

As a summary, the early stage of COVID-19 pandemic caused significant negative impact to the stock market performance. Yet, there is no answer for the ending date of the pandemic. The impacts may change over the time. Under such a circumstance, event study methodology may not be the appropriate method to investigate the impact of COVID-19 pandemic since it only focused on a single event or announcement. In addition, the impact of COVID-19 pandemic has to be observed over the time.

\section{Data and Methodology}

COVID-19 pandemic was not a short-term event. Al-Awadhi et al. (2020) suggested that the event study methodologies were not appropriate to be used in investigating the impact of the COVID-19 pandemic. Thus, this study applies the both the ordinary least square (OLS) regression analysis and quantile regression analysis to investigate whether the 
Malaysian stock market immune to the COVID-19 related information. The OLS regression analysis typically assumes the association between independent variables and dependent variable is linear. In contrast, quantile regression provides multiple estimators for each quantile, which allows the investigation of the varied impacts of the independent variables on the dependent variable. As a result, it provides a more precise method for comparing its estimated coefficients and standard errors to OLS regression. Another benefit of quantile regression is that it is less sensitive to the tail behaviour of the underlying random variables, and hence it is less vulnerable to outliers and has a higher breakdown point than OLS regression (Alsayed et al., 2020). Quantile regression is not calculated on a quantile or subsample of data. The quantile regression also helps to relax the standard regression slope assumption. On the other hand, quantile regression weights the distances between the regression line's projected values and the actual values differently and then attempts to minimize the weighted distances. In contrast, OLS regression only minimizes the distances between the regression line's projected and actual values (Cook \& Manning, 2013).

The dependent variables used in this study are the sectoral indexes. Whereas, the independent variables are the market volatility, proxy of oil price, COVID-19 confirmed cases and death cases. The sample period of this study covered from 2 January 2020 to 31 December 2021. For the dependent variable, this study used the daily data of 13 sectoral indexes (as shown in Table 1) in Kuala Lumpur Stock Exchange. For the independent variable, the market volatility is represented by the standard deviation for the return of KLCl. Firstly, the daily return of the $\mathrm{KLCl}$ is calculated as below:

$$
\text { Daily return of } \mathrm{KLCl}=\ln \left(\frac{\mathrm{KLCI}_{\mathrm{t}}}{\mathrm{KLCI}_{\mathrm{t}-1}}\right)
$$

Then, the standard deviation is calculated as below:

$$
\text { Standard deviation for the return of } \mathrm{KLCl}=\sqrt{\frac{(x-\bar{x})^{2}}{n-1}}
$$

Besides that, the daily prices of the brent oil are used as the proxy of oil price. The source for the stock market related data and brent oil data is Investing.com. This study also used the number of daily COVID-19 confirmed cases and death cases in Malaysia from the website "Our World in Data". The regression model employed in this study are as follow:

$$
Q_{\tau}\left(S I_{i t}\right)=\beta_{0}(\tau)+\beta_{1}(\tau) \text { Volatility }_{t}+\beta_{2}(\tau) \text { Brent }_{t}+\beta_{3}(\tau) \text { Cases }_{t}+\beta_{4}(\tau) \text { Death }_{t}
$$

Where $\tau$ refers to the $50^{\text {th }}$ quantile; $S l_{i t}$ refers to the Sectoral Index of Sector $i$ at time $t$; Volatility $_{t}$ refers to the market volatility at time $t$; Brent $t_{t}$ refers to the brent oil price at time $t$;

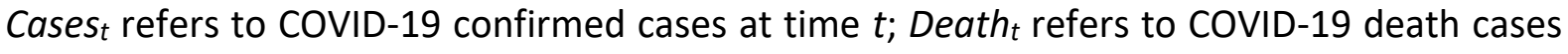
at time $t$. 
MANAGEMENT SCIENCES

Vol. 12 , No. 1, 2022, E-ISSN: 2225-8329 @ 2022 HRMARS

Table 1: Sectors in Malaysian Stock Market

\begin{tabular}{|l|l|}
\hline No. & Sector \\
\hline 1 & Consumer \\
\hline 2 & Construction \\
\hline 3 & Energy \\
\hline 4 & Finance \\
\hline 5 & Healthcare \\
\hline 6 & Industrial Product \\
\hline 7 & Plantation \\
\hline 8 & Property \\
\hline 9 & Real Estate Investment Fund \\
\hline 10 & Technology \\
\hline 11 & Telecommunication \\
\hline 12 & Transportation \\
\hline 13 & Utilities \\
\hline
\end{tabular}

Lastly, 13 quantile regression models are developed for 13 sectoral indexes. The quantile regression analysis will be carried out to examine the immunity of these sectoral indexes to COVID-19 related information and other factors.

\section{Result and Discussion}

This section presents the result of the study. Table 2 presents the descriptive statistics of 13 sectoral indexes in 2020 and 2021. As reported in Table 2, the healthcare sectoral index had the highest coefficient of variation (CV) of $44.1 \%$ in 2020 , followed by technology $(25.2 \%)$ and energy (22.2\%) sectors. This implied that the movements of these three sectors facing a huge fluctuation in 2020. These three sectors also had the higher CV than other sectors in 2021. On the other hand, the utilities sectoral index had the lowest CV of $4.7 \%$ in 2020, followed by REIT (6.0\%) and plantation (6.6\%) sectors. In 2021, the utilities and REIT sectoral index remain less volatile, with the $\mathrm{CV}$ of $3.3 \%$ and $1.8 \%$ respectively. In the aspect of volatility, the CV of finance sectoral index has dropped significantly from $8.7 \%$ to $1.9 \%$. The emergence of the COVID-19 pandemic has caused the Malaysian market to fluctuate significantly in 2020. The investors are uncertainly due to the deadly COVID-19 virus. The invention of the vaccine also recovers the investor's confidence. In summary, the volatility for the movements of all the sectoral indexes has decreased from 2020 to 2021. 
INTERNATIONAL JOURNAL OF ACADEMIC RESEARCH IN ACCOUNTING, FINANCE AND MANAGEMENT SCIENCES

Vol. 12 , No. 1, 2022, E-ISSN: 2225-8329 @ 2022 HRMARS

Table 2: Descriptive Statistics for the Sectoral indexes

\begin{tabular}{|c|c|c|c|c|c|c|}
\hline Sector & Year & Mean & Max & Min & SD & CV \\
\hline \multirow[t]{2}{*}{ Utilities } & 2020 & 947.539 & 1010.100 & 752.780 & 44.923 & 0.047 \\
\hline & 2021 & 916.007 & 980.330 & 848.180 & 30.248 & 0.033 \\
\hline \multirow[t]{2}{*}{ Energy } & 2020 & 838.336 & 1291.250 & 513.750 & 186.269 & 0.222 \\
\hline & 2021 & 818.372 & 1017.970 & 667.240 & 85.986 & 0.105 \\
\hline \multirow[t]{2}{*}{ Consumer Product } & 2020 & 575.102 & 658.000 & 466.270 & 38.319 & 0.067 \\
\hline & 2021 & 605.568 & 648.560 & 560.150 & 20.383 & 0.034 \\
\hline \multirow[t]{2}{*}{ Plantation } & 2020 & 6912.164 & 7810.200 & 5532.030 & 453.240 & 0.066 \\
\hline & 2021 & 6760.665 & 7483.570 & 6009.240 & 361.667 & 0.053 \\
\hline \multirow[t]{2}{*}{ Healthcare } & 2020 & 2700.521 & 4456.090 & 1142.400 & 1192.067 & 0.441 \\
\hline & 2021 & 2876.602 & 3667.740 & 2105.600 & 404.696 & 0.141 \\
\hline \multirow[t]{2}{*}{ Telecommunication } & 2020 & 610.118 & 718.240 & 483.540 & 43.353 & 0.071 \\
\hline & 2021 & 686.605 & 747.720 & 609.290 & 32.162 & 0.047 \\
\hline \multirow[t]{2}{*}{ Construction } & 2020 & 171.607 & 212.550 & 121.910 & 19.442 & 0.113 \\
\hline & 2021 & 169.416 & 188.730 & 150.730 & 9.275 & 0.055 \\
\hline \multirow[t]{2}{*}{ Technology } & 2020 & 47.475 & 69.720 & 23.810 & 11.974 & 0.252 \\
\hline & 2021 & 87.833 & 100.860 & 66.720 & 7.781 & 0.089 \\
\hline \multirow[t]{2}{*}{ Transport } & 2020 & 680.835 & 801.250 & 480.710 & 66.029 & 0.097 \\
\hline & 2021 & 844.624 & 936.010 & 735.320 & 45.040 & 0.053 \\
\hline \multirow[t]{2}{*}{ Industrial Product } & 2020 & 139.357 & 178.920 & 92.520 & 18.067 & 0.130 \\
\hline & 2021 & 192.654 & 213.410 & 169.190 & 9.100 & 0.047 \\
\hline \multirow[t]{2}{*}{ Property } & 2020 & 655.616 & 831.670 & 495.190 & 74.837 & 0.114 \\
\hline & 2021 & 722.496 & 789.360 & 667.080 & 27.607 & 0.038 \\
\hline \multirow[t]{2}{*}{ Finance } & 2020 & 13407.338 & 16046.130 & 10885.450 & 1164.605 & 0.087 \\
\hline & 2021 & 15138.921 & 15937.770 & 14448.580 & 293.086 & 0.019 \\
\hline \multirow[t]{2}{*}{ REIT } & 2020 & 873.435 & 980.100 & 780.160 & 52.535 & 0.060 \\
\hline & 2021 & 813.188 & 848.400 & 778.050 & 14.460 & 0.018 \\
\hline
\end{tabular}

Notes: Max $=$ maximum. Min $=$ minimum $. S \cdot D=$ standard deviation. $C V=$ coefficient of variation

Table 3 present the result of correlation analysis for the sectoral indexes in 2020. The three strongest positive correlation were found in between property sectoral index and the other three indexes - energy, consumer product and construction sectoral indexes, with the correlation ranged between 0.9512 and 0.9582 . Meanwhile, the three strongest negative correlations were found in between REIT and healthcare $(-0.6679)$, followed by REIT and technology (-0.4784), and telecommunication and healthcare (0.2536).

Table 4 present the result of correlation analysis for the sectoral indexes in 2021. The three strongest positive correlation were found in between construction and consumer product sectoral index (0.9088), followed by utilities and energy sectoral index (0.8653) and construction and REIT (0.8647). Whereas the three negative correlations were found in between healthcare and technology sectors $(-0.7927)$, followed by healthcare and industrial product $(-0.7126)$ and healthcare and transportation sectors $(-0.7118)$. 
INTERNATIONAL JOURNAL OF ACADEMIC RESEARCH IN ACCOUNTING, FINANCE AND MANAGEMENT SCIENCES

Vol. 12, No. 1, 2022, E-ISSN: 2225-8329 @ 2022 HRMARS

Table 3: Results of Correlation Analysis (2020)

\begin{tabular}{|c|c|c|c|c|c|c|c|c|c|c|c|c|c|}
\hline Sector & UTL & ENE & CP & PLT & $\begin{array}{c}\text { HEA } \\
\text { L }\end{array}$ & TELE & $\begin{array}{c}\text { CON } \\
\mathrm{S}\end{array}$ & $\begin{array}{c}\text { TEC } \\
\mathbf{H}\end{array}$ & $\begin{array}{c}\text { TRA } \\
\text { NS }\end{array}$ & IP & PRO & FIN & REIT \\
\hline UTL & $\begin{array}{c}1.00 \\
00\end{array}$ & & & & & & & & & & & & \\
\hline ENE & $\begin{array}{c}0.56 \\
55\end{array}$ & $\begin{array}{c}1.00 \\
00\end{array}$ & & & & & & & & & & & \\
\hline $\mathrm{CP}$ & $\begin{array}{c}0.80 \\
84\end{array}$ & $\begin{array}{c}0.90 \\
65\end{array}$ & $\begin{array}{c}1.00 \\
00\end{array}$ & & & & & & & & & & \\
\hline PLT & $\begin{array}{c}0.86 \\
76\end{array}$ & $\begin{array}{c}0.63 \\
83 \\
\end{array}$ & $\begin{array}{c}0.86 \\
10 \\
\end{array}$ & $\begin{array}{c}1.00 \\
00\end{array}$ & & & & & & & & & \\
\hline HEAL & $\begin{array}{c}0.36 \\
56\end{array}$ & $\begin{array}{c}- \\
0.37 \\
68\end{array}$ & $\begin{array}{c}- \\
0.03 \\
07\end{array}$ & $\begin{array}{c}0.41 \\
02\end{array}$ & $\begin{array}{c}1.00 \\
00\end{array}$ & & & & & & & & \\
\hline TELE & $\begin{array}{c}0.64 \\
96\end{array}$ & $\begin{array}{c}0.79 \\
23\end{array}$ & $\begin{array}{c}0.80 \\
47\end{array}$ & $\begin{array}{c}0.56 \\
42\end{array}$ & $\begin{array}{c}- \\
0.25 \\
36\end{array}$ & $\begin{array}{c}1.00 \\
00\end{array}$ & & & & & & & \\
\hline CONS & $\begin{array}{c}0.72 \\
72\end{array}$ & $\begin{array}{c}0.93 \\
89\end{array}$ & $\begin{array}{c}0.94 \\
88\end{array}$ & $\begin{array}{c}0.72 \\
59\end{array}$ & $\begin{array}{c}- \\
0.24 \\
97\end{array}$ & $\begin{array}{c}0.88 \\
48\end{array}$ & $\begin{array}{c}1.00 \\
00\end{array}$ & & & & & & \\
\hline TECH & $\begin{array}{c}0.53 \\
98\end{array}$ & $\begin{array}{c} \\
0.09 \\
09\end{array}$ & $\begin{array}{c}0.25 \\
56\end{array}$ & $\begin{array}{c}0.62 \\
85\end{array}$ & $\begin{array}{c}0.89 \\
98\end{array}$ & $\begin{array}{c}0.03 \\
53\end{array}$ & $\begin{array}{c}0.05 \\
33\end{array}$ & $\begin{array}{c}1.00 \\
00\end{array}$ & & & & & \\
\hline TRANS & $\begin{array}{c}0.86 \\
29\end{array}$ & $\begin{array}{c}0.66 \\
84\end{array}$ & $\begin{array}{c}0.87 \\
68\end{array}$ & $\begin{array}{c}0.88 \\
53\end{array}$ & $\begin{array}{c}0.26 \\
17\end{array}$ & $\begin{array}{c}0.77 \\
94\end{array}$ & $\begin{array}{c}0.81 \\
35\end{array}$ & $\begin{array}{c}0.54 \\
83\end{array}$ & $\begin{array}{c}1.00 \\
00\end{array}$ & & & & \\
\hline IP & $\begin{array}{c}0.79 \\
62 \\
\end{array}$ & $\begin{array}{c}0.48 \\
31\end{array}$ & $\begin{array}{c}0.75 \\
19\end{array}$ & $\begin{array}{c}0.89 \\
03\end{array}$ & $\begin{array}{c}0.50 \\
38\end{array}$ & $\begin{array}{c}0.55 \\
50\end{array}$ & $\begin{array}{c}0.62 \\
47\end{array}$ & $\begin{array}{c}0.77 \\
53\end{array}$ & $\begin{array}{c}0.92 \\
23\end{array}$ & $\begin{array}{c}1.00 \\
00\end{array}$ & & & \\
\hline PRO & $\begin{array}{c}0.66 \\
94\end{array}$ & $\begin{array}{c}0.95 \\
82\end{array}$ & $\begin{array}{c}0.95 \\
12\end{array}$ & $\begin{array}{c}0.73 \\
42\end{array}$ & $\begin{array}{c}- \\
0.22 \\
54\end{array}$ & $\begin{array}{c}0.82 \\
48\end{array}$ & $\begin{array}{c}0.95 \\
30\end{array}$ & $\begin{array}{c}0.09 \\
74\end{array}$ & $\begin{array}{c}0.79 \\
23\end{array}$ & $\begin{array}{c}0.65 \\
64\end{array}$ & $\begin{array}{c}1.00 \\
00\end{array}$ & & \\
\hline FIN & $\begin{array}{c}0.61 \\
64\end{array}$ & $\begin{array}{c}0.83 \\
11\end{array}$ & $\begin{array}{c}0.89 \\
02\end{array}$ & $\begin{array}{c}0.73 \\
12\end{array}$ & $\begin{array}{c}- \\
0.11 \\
15\end{array}$ & $\begin{array}{c}0.74 \\
88\end{array}$ & $\begin{array}{c}0.85 \\
53\end{array}$ & $\begin{array}{c}0.21 \\
91\end{array}$ & $\begin{array}{c}0.82 \\
42\end{array}$ & $\begin{array}{c}0.75 \\
20\end{array}$ & $\begin{array}{c}0.91 \\
78\end{array}$ & $\begin{array}{c}1.00 \\
00\end{array}$ & \\
\hline REIT & $\begin{array}{c}0.31 \\
30\end{array}$ & $\begin{array}{c}0.85 \\
03\end{array}$ & $\begin{array}{c}0.67 \\
77\end{array}$ & $\begin{array}{c}0.26 \\
77\end{array}$ & $\begin{array}{c}- \\
0.66 \\
79\end{array}$ & $\begin{array}{c}0.66 \\
37\end{array}$ & $\begin{array}{c}0.77 \\
80\end{array}$ & $\begin{array}{c}- \\
0.47 \\
84\end{array}$ & $\begin{array}{c}0.35 \\
79\end{array}$ & $\begin{array}{c}0.09 \\
73\end{array}$ & $\begin{array}{c}0.77 \\
08\end{array}$ & $\begin{array}{c}0.63 \\
07\end{array}$ & $\begin{array}{c}1.00 \\
00\end{array}$ \\
\hline
\end{tabular}


INTERNATIONAL JOURNAL OF ACADEMIC RESEARCH IN ACCOUNTING, FINANCE AND MANAGEMENT SCIENCES

Vol. 12, No. 1, 2022, E-ISSN: 2225-8329 @ 2022 HRMARS

Table 4: Results of Correlation Analysis (2021)

\begin{tabular}{|c|c|c|c|c|c|c|c|c|c|c|c|c|c|}
\hline $\begin{array}{l}\text { Sect } \\
\text { or }\end{array}$ & UTL & ENE & CP & PLT & $\begin{array}{c}\text { HEA } \\
\mathrm{L}\end{array}$ & TELE & $\begin{array}{c}\text { CON } \\
\mathrm{S}\end{array}$ & TECH & $\begin{array}{l}\text { TRA } \\
\text { NS }\end{array}$ & IP & PRO & FIN & REIT \\
\hline UTL & $\begin{array}{c}1.00 \\
00\end{array}$ & & & & & & & & & & & & \\
\hline ENE & $\begin{array}{c}0.86 \\
53\end{array}$ & $\begin{array}{c}1.00 \\
00\end{array}$ & & & & & & & & & & & \\
\hline $\mathrm{CP}$ & $\begin{array}{c}0.78 \\
85\end{array}$ & $\begin{array}{c}0.80 \\
53\end{array}$ & $\begin{array}{c}1.00 \\
00\end{array}$ & & & & & & & & & & \\
\hline PLT & $\begin{array}{c}0.69 \\
32 \\
\end{array}$ & $\begin{array}{c}0.77 \\
79 \\
\end{array}$ & $\begin{array}{c}0.53 \\
12 \\
\end{array}$ & $\begin{array}{c}1.00 \\
00 \\
\end{array}$ & & & & & & & & & \\
\hline $\begin{array}{c}\text { HEA } \\
\mathrm{L}\end{array}$ & $\begin{array}{c}0.81 \\
11 \\
\end{array}$ & $\begin{array}{c}0.67 \\
15 \\
\end{array}$ & $\begin{array}{c}0.36 \\
31 \\
\end{array}$ & $\begin{array}{c}0.63 \\
94 \\
\end{array}$ & $\begin{array}{c}1.00 \\
00 \\
\end{array}$ & & & & & & & & \\
\hline TELE & $\begin{array}{c}0.74 \\
03\end{array}$ & $\begin{array}{c}0.69 \\
19\end{array}$ & $\begin{array}{c}0.84 \\
54\end{array}$ & $\begin{array}{c}0.24 \\
28 \\
\end{array}$ & $\begin{array}{c}0.43 \\
45\end{array}$ & $\begin{array}{c}1.00 \\
00\end{array}$ & & & & & & & \\
\hline $\begin{array}{c}\text { CON } \\
\mathrm{S} \\
\end{array}$ & $\begin{array}{c}0.85 \\
30 \\
\end{array}$ & $\begin{array}{c}0.86 \\
29 \\
\end{array}$ & $\begin{array}{c}0.90 \\
88 \\
\end{array}$ & $\begin{array}{c}0.62 \\
49 \\
\end{array}$ & $\begin{array}{c}0.54 \\
81 \\
\end{array}$ & $\begin{array}{c}0.78 \\
23 \\
\end{array}$ & $\begin{array}{c}1.00 \\
00 \\
\end{array}$ & & & & & & \\
\hline $\begin{array}{c}\text { TEC } \\
\mathrm{H}\end{array}$ & $\begin{array}{c}- \\
0.65 \\
51 \\
\end{array}$ & $\begin{array}{c}- \\
0.51 \\
33 \\
\end{array}$ & $\begin{array}{c}- \\
0.22 \\
49 \\
\end{array}$ & $\begin{array}{c}- \\
0.42 \\
64 \\
\end{array}$ & $\begin{array}{c}- \\
0.79 \\
27 \\
\end{array}$ & $\begin{array}{c}- \\
0.33 \\
90\end{array}$ & $\begin{array}{c}- \\
0.44 \\
84 \\
\end{array}$ & $\begin{array}{c}1.00 \\
00\end{array}$ & & & & & \\
\hline $\begin{array}{l}\text { TRA } \\
\text { NS }\end{array}$ & $\begin{array}{c}- \\
0.42 \\
27 \\
\end{array}$ & $\begin{array}{c}- \\
0.38 \\
21 \\
\end{array}$ & $\begin{array}{c}0.02 \\
60\end{array}$ & $\begin{array}{c}- \\
0.50 \\
27 \\
\end{array}$ & $\begin{array}{c}- \\
0.71 \\
18 \\
\end{array}$ & $\begin{array}{c}0.04 \\
11\end{array}$ & $\begin{array}{c}- \\
0.15 \\
40 \\
\end{array}$ & $\begin{array}{c}0.60 \\
09\end{array}$ & $\begin{array}{c}1.00 \\
00\end{array}$ & & & & \\
\hline IP & $\begin{array}{c}- \\
0.35 \\
51 \\
\end{array}$ & $\begin{array}{c}- \\
0.22 \\
37 \\
\end{array}$ & $\begin{array}{c}0.20 \\
84\end{array}$ & $\begin{array}{c}- \\
0.27 \\
23 \\
\end{array}$ & $\begin{array}{c}- \\
0.71 \\
26 \\
\end{array}$ & $\begin{array}{c}0.07 \\
11\end{array}$ & $\begin{array}{c}0.00 \\
66\end{array}$ & $\begin{array}{c}0.68 \\
17\end{array}$ & $\begin{array}{c}0.83 \\
83\end{array}$ & $\begin{array}{c}1.00 \\
00\end{array}$ & & & \\
\hline PRO & $\begin{array}{c}0.36 \\
46\end{array}$ & $\begin{array}{c}0.47 \\
92\end{array}$ & $\begin{array}{c}0.77 \\
28\end{array}$ & $\begin{array}{c}0.28 \\
14\end{array}$ & $\begin{array}{c}- \\
0.08 \\
12\end{array}$ & $\begin{array}{c}0.56 \\
60\end{array}$ & $\begin{array}{c}0.71 \\
06\end{array}$ & $\begin{array}{c}0.12 \\
57\end{array}$ & $\begin{array}{c}0.43 \\
40\end{array}$ & $\begin{array}{c}0.58 \\
99\end{array}$ & $\begin{array}{c}1.00 \\
00\end{array}$ & & \\
\hline FIN & $\begin{array}{c}0.01 \\
05\end{array}$ & $\begin{array}{c}0.08 \\
74\end{array}$ & $\begin{array}{c}0.35 \\
49\end{array}$ & $\begin{array}{c}0.11 \\
51\end{array}$ & $\begin{array}{c}- \\
0.43 \\
66\end{array}$ & $\begin{array}{c}0.12 \\
23\end{array}$ & $\begin{array}{c}0.22 \\
45\end{array}$ & $\begin{array}{c}0.30 \\
59\end{array}$ & $\begin{array}{c}0.52 \\
69\end{array}$ & $\begin{array}{c}0.60 \\
91\end{array}$ & $\begin{array}{c}0.55 \\
29\end{array}$ & $\begin{array}{c}1.00 \\
00\end{array}$ & \\
\hline REIT & $\begin{array}{c}0.73 \\
71\end{array}$ & $\begin{array}{c}0.70 \\
41\end{array}$ & $\begin{array}{c}0.85 \\
36\end{array}$ & $\begin{array}{c}0.42 \\
88\end{array}$ & $\begin{array}{c}0.38 \\
23\end{array}$ & $\begin{array}{c}0.73 \\
43\end{array}$ & $\begin{array}{c}0.86 \\
47\end{array}$ & $\begin{array}{c}- \\
0.24 \\
70\end{array}$ & $\begin{array}{c}0.06 \\
67\end{array}$ & $\begin{array}{c}0.08 \\
06\end{array}$ & $\begin{array}{c}0.72 \\
15\end{array}$ & $\begin{array}{c}0.27 \\
26\end{array}$ & $\begin{array}{c}1.00 \\
00\end{array}$ \\
\hline
\end{tabular}

Notes: UTL refers to Utilities; ENE refers to Energy; CP refers to Consumer Product; PLT refers to Plantation; HEAL refers to Healthcare; TELE refers to Telecommunication; CONS refers to Construction; TECH refers to Technology; TRANS refers to Transportation; IP refers to Industrial Product; PRO refers to Property; FIN refers to Finance; REIT refers to Real Estate Investment Trust 
INTERNATIONAL JOURNAL OF ACADEMIC RESEARCH IN ACCOUNTING, FINANCE AND MANAGEMENT SCIENCES

Vol. 12 , No. 1, 2022, E-ISSN: 2225-8329 @ 2022 HRMARS

Table 5: Result of Quantile Regression Analysis (Year 2020)

\begin{tabular}{|c|c|c|c|c|c|c|c|c|c|c|c|c|c|}
\hline VAR & UTL & ENE & CP & PLT & HEAL & TELE & CONS & TECH & $\begin{array}{c}\text { TRAN } \\
\mathrm{S} \\
\end{array}$ & IP & PRO & FIN & REIT \\
\hline $\begin{array}{c}\text { volati } \\
\text { lity }\end{array}$ & $\begin{array}{c}- \\
0.448 \\
0 * * *\end{array}$ & $\begin{array}{c}1.356 \\
0 * *\end{array}$ & $\begin{array}{c}- \\
0.009 \\
8\end{array}$ & $\begin{array}{c}- \\
3.046 \\
0 * * *\end{array}$ & $\begin{array}{c}- \\
30.37 \\
* * *\end{array}$ & $\begin{array}{c}0.127 \\
0\end{array}$ & $\begin{array}{c}0.000 \\
9\end{array}$ & $\begin{array}{c}- \\
0.266 \\
0 * * *\end{array}$ & $\begin{array}{c}- \\
0.107 \\
0\end{array}$ & $\begin{array}{c}- \\
0.036 \\
9\end{array}$ & $\begin{array}{c}0.395 \\
0 *\end{array}$ & $\begin{array}{c}14.33 \\
* * *\end{array}$ & $\begin{array}{l}0.580 \\
0 * * *\end{array}$ \\
\hline & $\begin{array}{c}- \\
0.129 \\
0\end{array}$ & $\begin{array}{c}- \\
0.581 \\
0\end{array}$ & $\begin{array}{c}- \\
0.051 \\
5\end{array}$ & $\begin{array}{c}- \\
0.819 \\
0\end{array}$ & $\begin{array}{c}- \\
8.109 \\
0\end{array}$ & $\begin{array}{c}- \\
0.152 \\
0\end{array}$ & $\begin{array}{c}- \\
0.054 \\
4 \\
\end{array}$ & $\begin{array}{c}- \\
0.052 \\
8\end{array}$ & $\begin{array}{c}- \\
0.172 \\
0\end{array}$ & $\begin{array}{c}- \\
0.037 \\
1\end{array}$ & $\begin{array}{c}- \\
0.215 \\
0\end{array}$ & $\begin{array}{c}- \\
2.876 \\
0\end{array}$ & $\begin{array}{c}- \\
0.163 \\
0\end{array}$ \\
\hline brent & $\begin{array}{c}2.002 \\
* * *\end{array}$ & $\begin{array}{c}19.40 \\
* * *\end{array}$ & $\begin{array}{c}3.474 \\
0 * * *\end{array}$ & $\begin{array}{c}33.06 \\
* * *\end{array}$ & $\begin{array}{c}- \\
50.82 \\
* * *\end{array}$ & $\begin{array}{l}3.617 \\
0 * * *\end{array}$ & $\begin{array}{l}1.752 \\
0 * * *\end{array}$ & $\begin{array}{c}- \\
0.105 \\
0\end{array}$ & $\begin{array}{l}4.313 \\
0 * * *\end{array}$ & $\begin{array}{l}0.904 \\
0 * * *\end{array}$ & $\begin{array}{l}7.893 \\
0 * * *\end{array}$ & $\begin{array}{c}108.9 \\
* * *\end{array}$ & $\begin{array}{c}3.908 \\
0 * * *\end{array}$ \\
\hline & $\begin{array}{c}- \\
0.260 \\
0\end{array}$ & $\begin{array}{c}- \\
1.175 \\
0\end{array}$ & $\begin{array}{c}- \\
0.104 \\
0\end{array}$ & $\begin{array}{c}- \\
1.655 \\
0\end{array}$ & $\begin{array}{c}- \\
16.39\end{array}$ & $\begin{array}{c}- \\
0.306 \\
0\end{array}$ & $\begin{array}{c}- \\
0.110 \\
0\end{array}$ & $\begin{array}{c}- \\
0.107 \\
0\end{array}$ & $\begin{array}{c}- \\
0.348 \\
0\end{array}$ & $\begin{array}{c}- \\
0.075 \\
0\end{array}$ & $\begin{array}{c}- \\
0.435 \\
0\end{array}$ & $\begin{array}{c}- \\
5.814 \\
0\end{array}$ & $\begin{array}{c}- \\
0.330 \\
0\end{array}$ \\
\hline cases & $\begin{array}{c}0.007 \\
1 \\
\end{array}$ & $\begin{array}{c}- \\
0.063 \\
1 * *\end{array}$ & $\begin{array}{c}0.003 \\
5 \\
\end{array}$ & $\begin{array}{l}0.170 \\
0 * * *\end{array}$ & $\begin{array}{c}1.224 \\
0 * * *\end{array}$ & $\begin{array}{c}0.011 \\
2^{*}\end{array}$ & $\begin{array}{c}- \\
0.000 \\
5 \\
\end{array}$ & $\begin{array}{c}0.017 \\
1^{* * *}\end{array}$ & $\begin{array}{l}0.052 \\
4^{* * *}\end{array}$ & $\begin{array}{l}0.020 \\
0 * * *\end{array}$ & $\begin{array}{c}- \\
0.000 \\
9\end{array}$ & $\begin{array}{c}0.586 \\
9 * * *\end{array}$ & $\begin{array}{c}- \\
0.041 \\
3^{* * *}\end{array}$ \\
\hline & $\begin{array}{c}- \\
0.005 \\
5\end{array}$ & $\begin{array}{c}- \\
0.024 \\
7\end{array}$ & $\begin{array}{c}- \\
0.002 \\
2\end{array}$ & $\begin{array}{c}- \\
0.034 \\
7\end{array}$ & $\begin{array}{c}- \\
0.344 \\
0\end{array}$ & $\begin{array}{c}- \\
0.006 \\
4\end{array}$ & $\begin{array}{c}- \\
0.002 \\
3\end{array}$ & $\begin{array}{c}- \\
0.002 \\
2\end{array}$ & $\begin{array}{c}- \\
0.007 \\
3 \\
\end{array}$ & $\begin{array}{c}- \\
0.001 \\
6\end{array}$ & $\begin{array}{c}- \\
0.009 \\
1\end{array}$ & $\begin{array}{c}- \\
0.122 \\
9\end{array}$ & $\begin{array}{c}- \\
0.006 \\
9\end{array}$ \\
\hline death & $\begin{array}{c}0.354 \\
0 \\
\end{array}$ & $\begin{array}{c}- \\
4.345 \\
0 \\
\end{array}$ & $\begin{array}{c}- \\
1.590 \\
0 * * *\end{array}$ & $\begin{array}{c}- \\
1.610 \\
0\end{array}$ & 42.89 & $\begin{array}{c}- \\
3.857 \\
0 * *\end{array}$ & $\begin{array}{c}- \\
0.761 \\
0 \\
\end{array}$ & $\begin{array}{c}0.329 \\
0 \\
\end{array}$ & $\begin{array}{c}- \\
4.600 \\
0 * *\end{array}$ & $\begin{array}{c}- \\
0.475 \\
0\end{array}$ & $\begin{array}{c}- \\
2.128 \\
0 \\
\end{array}$ & $\begin{array}{c}- \\
80.22 \\
* *\end{array}$ & $\begin{array}{c}- \\
3.315 \\
0 *\end{array}$ \\
\hline & $\begin{array}{c}- \\
1.408 \\
0\end{array}$ & $\begin{array}{c}- \\
6.369 \\
0\end{array}$ & $\begin{array}{c}- \\
0.564 \\
0\end{array}$ & $\begin{array}{c}- \\
8.968 \\
0\end{array}$ & $\begin{array}{c}- \\
88.82\end{array}$ & $\begin{array}{c}- \\
1.661 \\
0\end{array}$ & $\begin{array}{c}- \\
0.595 \\
0\end{array}$ & $\begin{array}{c}- \\
0.579 \\
0\end{array}$ & $\begin{array}{c}- \\
1.888 \\
0\end{array}$ & $\begin{array}{c}- \\
0.406 \\
0\end{array}$ & $\begin{array}{c}- \\
2.358 \\
0\end{array}$ & $\begin{array}{c}- \\
31.50\end{array}$ & $\begin{array}{c}- \\
1.786 \\
0\end{array}$ \\
\hline $\begin{array}{c}\text { Const } \\
\text { ant }\end{array}$ & $\begin{array}{c}873.8 \\
* * *\end{array}$ & $\begin{array}{c}- \\
46.65 \\
\end{array}$ & $\begin{array}{c}424.3 \\
* * *\end{array}$ & $\begin{array}{c}5,547 \\
* * *\end{array}$ & $\begin{array}{c}5,356 \\
* * *\end{array}$ & $\begin{array}{c}440.7 \\
* * *\end{array}$ & $\begin{array}{c}95.68 \\
* * *\end{array}$ & $\begin{array}{c}53.09 \\
* * *\end{array}$ & $\begin{array}{c}488.3 \\
* * *\end{array}$ & $\begin{array}{c}96.56 \\
* * *\end{array}$ & $\begin{array}{c}295.5 \\
* * *\end{array}$ & $\begin{array}{c}8,113 \\
* * *\end{array}$ & $\begin{array}{c}701.8 \\
* * *\end{array}$ \\
\hline & $\begin{array}{c}- \\
13.68 \\
\end{array}$ & $\begin{array}{c}- \\
61.86 \\
\end{array}$ & $\begin{array}{c}- \\
5.479\end{array}$ & $\begin{array}{c}- \\
87.11\end{array}$ & $\begin{array}{c}- \\
862.8 \\
\end{array}$ & $\begin{array}{c}- \\
16.13 \\
\end{array}$ & $\begin{array}{c}- \\
5.784\end{array}$ & $\begin{array}{c}- \\
5.622\end{array}$ & $\begin{array}{c}- \\
18.34 \\
\end{array}$ & $\begin{array}{c}- \\
3.948\end{array}$ & $\begin{array}{c}- \\
22.91 \\
\end{array}$ & -306 & $\begin{array}{c}- \\
17.34 \\
\end{array}$ \\
\hline
\end{tabular}


INTERNATIONAL JOURNAL OF ACADEMIC RESEARCH IN ACCOUNTING, FINANCE AND

MANAGEMENT SCIENCES

Vol. 12, No. 1, 2022, E-ISSN: 2225-8329 @ 2022 HRMARS

Table 6: Result of Quantile Regression Analysis (Year 2021)

\begin{tabular}{|c|c|c|c|c|c|c|c|c|c|c|c|c|c|}
\hline VAR & UTL & ENE & CP & PLT & HEAL & TELE & CONS & TECH & $\begin{array}{c}\text { TRAN } \\
\mathrm{S}\end{array}$ & IP & PRO & FIN & REIT \\
\hline $\begin{array}{l}\text { volati } \\
\text { lity }\end{array}$ & $\begin{array}{c}- \\
0.433 \\
0 * * \\
\end{array}$ & $\begin{array}{c}0.012 \\
2 \\
\end{array}$ & $\begin{array}{c}0.05 \\
80 \\
\end{array}$ & $\begin{array}{c}18.24 \\
* * * \\
\end{array}$ & $\begin{array}{c} \\
7.86 \\
5^{* * *} \\
\end{array}$ & $\begin{array}{c}- \\
1.01 \\
0 * * \\
\end{array}$ & $\begin{array}{c}- \\
0.016 \\
3 \\
\end{array}$ & $\begin{array}{c}0.012 \\
4 \\
\end{array}$ & $\begin{array}{c}0.539 \\
0 * * \\
\end{array}$ & $\begin{array}{l}0.203 \\
0 * * *\end{array}$ & $\begin{array}{c}0.925 \\
0 * * \\
\end{array}$ & $\begin{array}{c}16.34 \\
* * * \\
\end{array}$ & $\begin{array}{r}0.36 \\
40 * * \\
\end{array}$ \\
\hline & $\begin{array}{c}- \\
0.214 \\
0 \\
\end{array}$ & $\begin{array}{c}- \\
0.680 \\
0\end{array}$ & $\begin{array}{c}- \\
0.30 \\
30 \\
\end{array}$ & $\begin{array}{c}- \\
2.693 \\
0 \\
\end{array}$ & $\begin{array}{c}- \\
2.63 \\
70 \\
\end{array}$ & $\begin{array}{c}- \\
0.47 \\
30 \\
\end{array}$ & $\begin{array}{c}- \\
0.118 \\
0 \\
\end{array}$ & $\begin{array}{c}- \\
0.074 \\
9 \\
\end{array}$ & $\begin{array}{c}- \\
0.267 \\
0 \\
\end{array}$ & $\begin{array}{c}- \\
0.068 \\
7 \\
\end{array}$ & $\begin{array}{c}- \\
0.375 \\
0 \\
\end{array}$ & $\begin{array}{c}- \\
3.079 \\
0 \\
\end{array}$ & $\begin{array}{c}- \\
0.18 \\
30 \\
\end{array}$ \\
\hline brent & $\begin{array}{c}- \\
1.916 \\
0 * * *\end{array}$ & $\begin{array}{c}- \\
4.147 \\
0 * * * \\
\end{array}$ & $\begin{array}{c}0.02 \\
56\end{array}$ & $\begin{array}{c}- \\
24.01 \\
* * *\end{array}$ & $\begin{array}{c}- \\
38.3 \\
8^{* * *} \\
\end{array}$ & $\begin{array}{c}- \\
0.89 \\
60 * *\end{array}$ & $\begin{array}{c}- \\
0.272 \\
0 * *\end{array}$ & $\begin{array}{l}0.661 \\
0 * * *\end{array}$ & $\begin{array}{l}4.906 \\
0 * * *\end{array}$ & $\begin{array}{l}0.897 \\
0 * * *\end{array}$ & $\begin{array}{l}1.367 \\
0 * * *\end{array}$ & $\begin{array}{c}18.31 \\
* * *\end{array}$ & $\begin{array}{c}0.07 \\
88\end{array}$ \\
\hline & $\begin{array}{c} \\
0.196 \\
0 \\
\end{array}$ & $\begin{array}{c}- \\
0.622 \\
0 \\
\end{array}$ & $\begin{array}{c}- \\
0.27 \\
70 \\
\end{array}$ & $\begin{array}{c}- \\
2.465 \\
0 \\
\end{array}$ & $\begin{array}{c}- \\
2.41 \\
50 \\
\end{array}$ & $\begin{array}{c}- \\
0.43 \\
30 \\
\end{array}$ & $\begin{array}{c}- \\
0.108 \\
0 \\
\end{array}$ & $\begin{array}{c}- \\
0.068 \\
5 \\
\end{array}$ & $\begin{array}{c} \\
0.244 \\
0 \\
\end{array}$ & $\begin{array}{c}- \\
0.062 \\
9 \\
\end{array}$ & $\begin{array}{c}- \\
0.343 \\
0 \\
\end{array}$ & $\begin{array}{c}- \\
2.819 \\
0 \\
\end{array}$ & $\begin{array}{c} \\
0.16 \\
80 \\
\end{array}$ \\
\hline cases & $\begin{array}{c}- \\
0.002 \\
9 * * *\end{array}$ & $\begin{array}{c}- \\
0.008 \\
8^{* * *} \\
\end{array}$ & $\begin{array}{c}- \\
0.00 \\
20 * * \\
\end{array}$ & $\begin{array}{c}- \\
0.027 \\
3 * * *\end{array}$ & $\begin{array}{c}- \\
0.00 \\
37 \\
\end{array}$ & $\begin{array}{c}- \\
0.00 \\
23^{*} \\
\end{array}$ & $\begin{array}{c}- \\
0.000 \\
8 * * *\end{array}$ & $\begin{array}{c}0.000 \\
06 \\
\end{array}$ & $\begin{array}{c}- \\
0.000 \\
05\end{array}$ & $\begin{array}{c}- \\
0.000 \\
3 \\
\end{array}$ & $\begin{array}{c}- \\
0.002 \\
1^{* *} \\
\end{array}$ & $\begin{array}{c}- \\
0.029 \\
4^{* * *}\end{array}$ & $\begin{array}{c}- \\
0.00 \\
02 \\
\end{array}$ \\
\hline & $\begin{array}{c}- \\
0.000 \\
6\end{array}$ & $\begin{array}{c}- \\
0.001 \\
8 \\
\end{array}$ & $\begin{array}{c}- \\
0.00 \\
08\end{array}$ & $\begin{array}{c}- \\
0.007 \\
0\end{array}$ & $\begin{array}{c}- \\
0.00 \\
68 \\
\end{array}$ & $\begin{array}{c}- \\
0.00 \\
12 \\
\end{array}$ & $\begin{array}{c}- \\
0.000 \\
3 \\
\end{array}$ & $\begin{array}{c}- \\
0.000 \\
2\end{array}$ & $\begin{array}{c}- \\
0.000 \\
7\end{array}$ & $\begin{array}{c}- \\
0.000 \\
2\end{array}$ & $\begin{array}{c}- \\
0.001 \\
0\end{array}$ & $\begin{array}{c}- \\
0.008 \\
0\end{array}$ & $\begin{array}{c}- \\
0.00 \\
05\end{array}$ \\
\hline deat & $\begin{array}{c}0.116 \\
0 * * * \\
\end{array}$ & $\begin{array}{c}0.024 \\
4 \\
\end{array}$ & $\begin{array}{c}0.07 \\
79 \\
\end{array}$ & $\begin{array}{c}- \\
0.332 \\
0 \\
\end{array}$ & $\begin{array}{c}- \\
0.17 \\
00 \\
\end{array}$ & $\begin{array}{c}0.11 \\
40 \\
\end{array}$ & $\begin{array}{c}0.025 \\
5 \\
\end{array}$ & $\begin{array}{c}0.000 \\
5 \\
\end{array}$ & $\begin{array}{c}0.059 \\
7 \\
\end{array}$ & $\begin{array}{c}0.013 \\
7 \\
\end{array}$ & $\begin{array}{c}0.043 \\
3 \\
\end{array}$ & $\begin{array}{c}0.815 \\
0^{*} \\
\end{array}$ & $\begin{array}{c} \\
0.01 \\
06 \\
\end{array}$ \\
\hline & $\begin{array}{c}- \\
0.034 \\
3\end{array}$ & $\begin{array}{c}- \\
0.109 \\
0\end{array}$ & $\begin{array}{c}- \\
0.04 \\
85\end{array}$ & $\begin{array}{c}- \\
0.432 \\
0\end{array}$ & $\begin{array}{c}- \\
0.42 \\
30\end{array}$ & $\begin{array}{c}- \\
0.07 \\
59\end{array}$ & $\begin{array}{c}- \\
0.019 \\
0\end{array}$ & $\begin{array}{c}- \\
0.012 \\
00\end{array}$ & $\begin{array}{c}- \\
0.042 \\
8\end{array}$ & $\begin{array}{c}- \\
0.011 \\
0\end{array}$ & $\begin{array}{c}- \\
0.060 \\
0\end{array}$ & $\begin{array}{c}- \\
0.493 \\
0\end{array}$ & $\begin{array}{c}- \\
0.02 \\
94\end{array}$ \\
\hline $\begin{array}{c}\text { Const } \\
\text { ant }\end{array}$ & $\begin{array}{c}1,075 \\
* * *\end{array}$ & $\begin{array}{c}1,189 \\
* * *\end{array}$ & $\begin{array}{l}609 . \\
0 * * *\end{array}$ & $\begin{array}{c}8,337 \\
* * *\end{array}$ & $\begin{array}{l}5,84 \\
2^{* * *}\end{array}$ & $\begin{array}{l}783 . \\
8 * * *\end{array}$ & $\begin{array}{c}191.8 \\
* * *\end{array}$ & $\begin{array}{c}41.70 \\
* * *\end{array}$ & $\begin{array}{c}480.5 \\
* * *\end{array}$ & $\begin{array}{c}125.8 \\
* * *\end{array}$ & $\begin{array}{c}616.5 \\
* * *\end{array}$ & $\begin{array}{l}13,68 \\
7 * * *\end{array}$ & $\begin{array}{l}803 . \\
2 * * *\end{array}$ \\
\hline & $\begin{array}{c}- \\
13.83\end{array}$ & $\begin{array}{c}- \\
43.96 \\
\end{array}$ & $\begin{array}{c}- \\
19.5 \\
7\end{array}$ & $\begin{array}{c}- \\
174.2\end{array}$ & $\begin{array}{c}- \\
170 . \\
6\end{array}$ & $\begin{array}{c}- \\
30.6 \\
2\end{array}$ & $\begin{array}{c}- \\
7.662\end{array}$ & $\begin{array}{c}- \\
4.842 \\
\end{array}$ & $\begin{array}{c}- \\
17.27\end{array}$ & $\begin{array}{c}- \\
4.441\end{array}$ & $\begin{array}{c}- \\
24.23\end{array}$ & $\begin{array}{c}- \\
199.1\end{array}$ & $\begin{array}{c}- \\
11.8 \\
7\end{array}$ \\
\hline
\end{tabular}

Notes: ${ }^{*} p<0.01,{ }^{* *} p<0.05,{ }^{* * *} p<0.10$; UTL refers to Utilities; ENE refers to Energy; $\mathrm{CP}$ refers to Consumer Product; PLT refers to Plantation; HEAL refers to Healthcare; TELE refers to Telecommunication; CONS refers to Construction; TECH refers to Technology; TRANS refers to Transportation; IP refers to Industrial Product; PRO refers to Property; FIN refers to Finance; REIT refers to Real Estate Investment Trust

Table 5 and Table 6 present the results of the quantile regression by using the data from the year 2020 and 2021. The market volatility was negatively related with the performance of sectoral indexes from utilities, plantation, healthcare, and technology sectors. Whereas the market volatility was positively related with the performance of sectoral indexes from energy, property, finance, and REIT sectors. However, market volatility does not pose any significant impact on the movements of consumer product, telecommunication, construction, transport, and industrial product sectoral indexes. This implied that the stock movements of these four sectors were immune to the market volatility in 2020. In addition, the movements of consumer product and construction sector continued immune to the market volatility in 2021. This suggest that consumer product and construction sector were the defensive sector to invest during the COVID-19 pandemic.

Consistently, the Brent oil price had the significant relationship with all the sectoral indexes, except for the technology sectoral index. This implied that the fluctuations in brent oil price do not affect the performance of technology sectoral index. The COVID-19 pandemic and Movement Control Order (MCO) occurred in 2020 also boost up the demand of technology products. Indirectly, the investor posed a high confidence towards technology 
MANAGEMENT SCIENCES

Vol. 12, No. 1, 2022, E-ISSN: 2225-8329 @ 2022 HRMARS

stocks in 2020. In 2021, the impact of brent oil price to the market movements remained the same for nearly all the sectors, except for the consumer product and REIT sectors. This result is not surprising since Malaysia is an oil exporting country. Thus, a monitor of brent oil price is needed before any investment action in Malaysian stock market.

In 2020, the daily COVID-19 confirmed cases also posted significant impact to the movements of nearly all the sectoral indexes, except for utilities, consumer product, construction, and property sectors. However, the COVID-19 confirmed cases posed significant impact to these three sectors in 2021. Surprisingly, the COVID-19 confirmed cases had no significant impact on the movements of other sectors, including healthcare, technology, transportation, industrial product and REIT sectors. This indicates that the impact of COVID19 confirmed cases towards the movements of sectoral indexes varies over the time.

In contrast, the daily COVID-19 death cases did not show much significant impact on the Malaysian stock market, since it only significantly related with the performance of five sectors - consumer product, telecommunication, transportation, finance and REIT sectors. The Malaysian stock market also started to immune to COVID-19 death cases as there were only two sectors - utilities and finance sector being affected significantly in 2021.

\section{Conclusion}

This study contributes to existing literature by testing whether the Malaysian sectoral indexes immune to the COVID-19 related news. This study carried out the quantile regression analysis by including the sectoral indexes as the dependent variables. Meanwhile, the independent variables consisted of the (i) market volatility, (ii) Brent oil price, (iii) daily COVID19 confirmed cases and (iv) daily COVID-19 death cases. The result of descriptive statistics indicated that the market volatility for all the sectoral indexes reduced from 2020 to 2021 . This suggests that the movements of Malaysian stock market have returned to the steadier level. Despite the market volatility has lower down recently, the impact of market volatility shall not be neglected. The results of quantile regression analysis revealed that the market volatility had significant relationship with nearly all the movements of sectoral indexes, except for the consumer product and construction sectors. Besides that, the results shown that Brent crude oil price was another essential factor to be considered by the investors before taking any investment action in Malaysian stock market. In addition, this study revealed that the impact of daily COVID-19 confirmed cases and death cases to the Malaysian stock market varies across the years. The daily COVID-19 death cases also posed a weaker impact to the Malaysian stock market than the daily COVID-19 confirmed cases. None of the sector consistently shown immunity to the COVID-19 related news in two consecutive years. The findings also suggest that healthcare, technology, transportation, industrial product, and REIT sectors started to immune to the daily COVID-19 confirmed cases. This may be due to the reopen of economic activities and well progressed vaccination programme tend recently. Intuitively, public may start to pay less attention to the impact of COVID-19, although several types of new variant COVID-19 virus have been detected recently. Investors should monitor and study the daily changes of COVID-19 confirmed cases. Any dramatic changes in the daily COVID-19 cases shall increase the volatility of Malaysian stock market. However, with the reopen of economic activities, investors are recommended to keep an eye on the REIT and technology sectors. A strong rebound in retail sales have been witnessed after the reopen of economic activities. In addition, the endless COVID-19 pandemic also led to the high demand in technological products. Finally, the findings provide investors clues about the potential industry to invest in, especially after the post-pandemic or early phase of the COVID-19 
MANAGEMENT SCIENCES

Vol. 12, No. 1, 2022, E-ISSN: 2225-8329 @ 2022 HRMARS

endemic. For further research, researchers can conduct further analysis by including more sample and considering the impact of reopening economic activities.

\section{Reference}

Al-Awadhi, A. M., Alsaifi, K., Al-Awadhi, A., \& Alhammadi, S. (2020). Death and contagious infectious diseases: Impact of the COVID-19 virus on stock market returns. Journal of Behavioral and Experimental Finance, 27, 1-5.

Alam, M. M., Wei, H., \& Wahid, A. N. M. (2020). COVID-19 outbreak and sectoral performance of the Australian stock market: An event study analysis. Australian Economic Papers, 114.

Alsayed, A. R. M., Isa, Z., Kun, S. S., \& Manzi, G. (2020). Quantile regression to tackle the heterogeneity on the relationship between economic growth, energy consumption, and CO2 emissions. Environmental Modeling and Assessment, 25(2), 251-258.

Ashraf, B. N. (2020). Stock markets' reaction to COVID-19: Cases or fatalities? Research in International Business and Finance, 54, 1-7.

Baek, S., Mohanty, S. K., \& Glambosky, M. (2020). COVID-19 and stock market volatility: An industry level analysis. Finance Research Letters, 37, 1-10.

Baharudin, S., Waked, H. N., \& Paimen, M. S. (2021). MCO in Malaysia: Consumer confidence and households' responses. Jurnal Ekonomi Malaysia, 55(1), 99-112.

Baig, A. S., Butt, H. A., Haroon, O., \& Rizvi, S. A. R. (2021). Deaths, panic, lockdowns and US equity markets: The case of COVID-19 pandemic. Finance Research Letters, 38, 1-9.

Baker, S. R., Bloom, N., Davis, S. J., Kost, K., Sammon, M., \& Viratyosin, T. (2020). The unprecedented stock market reaction to COVID-19. Review of Asset Pricing Studies, 117.

Chia, R. C. J., Liew, V. K. Sen, \& Rowland, R. (2020). Daily new COVID-19 cases, the Movement Control Order, and Malaysian stock market returns. International Journal of Business and Society, 21(2), 553-568.

Cook, B. L., \& Manning, W. G. (2013). Thinking beyond the mean: a practical guide for using quantile regression methods for health services research. Shanghai Archives of Psychiatry, 25(1), 55-59.

Donadelli, M., Kizys, R., \& Riedel, M. (2017). Dangerous infectious diseases: Bad news for Main Street, good news for Wall Street ? Journal of Financial Markets, 35, 84-103.

Fernandez-Perez, A., Glibert, A., Indriawan, I., \& Nguyen, N. H. (2021). COVID-19 pandemic and stock market response: A culture effect. Journal of Behavioral and Experimental Finance, 29, 1-10.

Gamal, A. A. M., Alqadasi, A. A., Ramli, N., \& Viswanathan, K. K. (2021). The impact of COVID19 on the Malaysian stock market: Evidence from an Autoregressive Distributed Lag Bound testing approach. Journal of Asian Finance Economics and Business, 8(7), 1-9.

Gormsen, N. J., \& Koijen, R. S. J. (2020). Coronavirus: Impact on Stock Prices and Growth Expectations. SSRN Electronic Journal, 1-34.

Harjoto, M. A., Rossi, F., Lee, R., \& Sergi, B. S. (2021). How do equity markets react to COVID19 ? Evidence from emerging and developed countries. Journal of Economics and Business, 1-38.

He, P., Sun, Y., Zhang, Y., \& Li, T. (2020). COVID-19's impact on stock prices across different sectors-An event study based on the Chinese stock market. Emerging Markets Finance and Trade, 56(10), 2198-2212.

Huo, X., \& Qiu, Z. (2020). How does China's stock market react to the announcement of the 
MANAGEMENT SCIENCES

Vol. 12 , No. 1, 2022, E-ISSN: 2225-8329 @ 2022 HRMARS

COVID-19 pandemic lockdown? Economic and Political Studies, 1-26.

Liu, H., Manzoor, A., Wang, C., Zhang, L., \& Manzoor, Z. (2020). The COVID-19 outbreak and affected countries stock markets response. International Journal of Environmental Research and Public Health, 17(2800), 1-19.

Maneenop, S., \& Kotcharin, S. (2020). The impacts of COVID-19 on the global airline industry: An event study approach. Journal of Air Transport Management, 89, 1-6.

Mazur, M., Dang, M., \& Vega, M. (2020). COVID-19 and the march 2020 stock market crash. Evidence from S\&P1500. Finance Research Letters, 1-8.

Mustaffa, A. H., Abidin, Z. N. B., Ahmad, N., \& Ogundare, A. E. (2021). Influence of COVID-19's active cases on Malaysia's key economic performance indicators. Journal of Emerging Economies and Islamic Research, 9(1), 68-87.

Naseem, S., Mohsin, M., Hui, W., Liyan, G., \& Penglai, K. (2021). The investor psychology and stock market behavior during the initial era of COVID-19: A study of China, Japan, and the United States. Frontiers in Psychology, 12, 1-10.

Rahim, M. H., Dom, N. C., Ismail, S. N. S., Mulud, Z. A., Abdullah, S., \& Pradhan, B. (2021). The impact of novel coronavirus (2019-nCoV) pandemic movement control order (MCO) on dengue cases in Peninsular Malaysia. One Health, 12, 1-9.

Rahman, M. L., Amin, A., \& Al Mamun, M. A. (2021). The COVID-19 outbreak and stock market reactions: Evidence from Australia. Finance Research Letters, 38, 1-7.

Ru, H., Yang, E., \& Zou, K. (2021). Combating the COVID-19 pandemic: The role of the SARS imprint. Management Science, 67(9), 5606-5615.

Shah, A. U. M., Safri, S. N. A., Thevadas, R., Noordin, N. K., Rahman, A. A., Sekawi, Z., Ideris, A., \& Sultan, M. T. H. (2020). COVID-19 outbreak in Malaysia: Actions taken by the Malaysian government. International Journal of Infectious Diseases, 97, 1-8.

Song, Y., Hao, X., \& Lu, Z. (2021). The impact of the Coronavirus Disease 2019 Pandemic on investor sentiment-Evidence from A-Share listed companies in China. Frontiers in Psychology, 12, 1-10.

Stubbs, T., Reinsberg, B., Kentikelenis, A., \& King, L. (2020). How to evaluate the effects of IMF conditionality: An extension of quantitative approaches and an empirical application to public education spending. Review of International Organizations, 15, 29-73.

Sun, Y., Bao, Q., \& Lu, Z. (2021). Coronavirus (Covid-19) outbreak, investor sentiment, and medical portfolio: Evidence from China, Hong Kong, Korea, Japan, and U.S. Pacific Basin Finance Journal, 65, 1-22.

Wang, Z., Zhang, Z., Zhang, Q., Gao, J., \& Lin, W. (2021). COVID-19 and financial market response in China: Micro evidence and possible mechanisms. PLOS ONE, 1-23. 